\title{
Satisfaction of Hypertension Patients Reviewed From Dimension Assurance at Community Health Center
}

\author{
Nerissa Nasriza,* Herbert Wau** \\ *M Author Correspondence: N_nasriza@yahoo.com \\ *Universitas Prima Indonesia, Medan, Sumatera Utara Indonesia \\ **Universitas Prima Indonesia, Medan, Sumatera Utara Indonesia

I NDE X I N G \\ Keywords: \\ Patient Satisfaction, \\ Assurance; \\ Community Health \\ Center;

\begin{abstract}
Patient satisfaction in health care is a reflection of the quality of service provided. Assurance service quality includes knowledge, ability, friendliness, courtesy, and trustworthiness. If Assurance is not implemented properly, it will cause problems so that it can affect patient satisfaction. The purpose of this study was to determine the relationship between the quality of Assurance services and hypertension patient satisfaction. This study was a qualitative study, with a descriptive research design. The sample in this study were 4 hypertension patients and 2 health workers with a total of 6 informants. The indepth interview results showed that there was a clear relationship between information, hospitality and thoroughness in service to the satisfaction of hypertensive patients at the Community Health Center.
\end{abstract}

\begin{abstract}
Kata Kunci:
Kepuasan Pasien;

Jaminan;

Community Health

Center;

Kepuasan pasien dalam pelayanan kesehatan merupakan cerminan dari kualitas pelayanan yang diberikan. Kualitas pelayanan Jaminan asuransi meliputi pengetahuan, kemampuan, keramahan, kesopanan, dan sifat dapat dipercaya. Bila Assurance tidak diterapkan dengan baik maka akan menimbulkan masalah sehingga dapat berpengaruh terhadap kepuasan pasien. Tujuan penelitian untuk mengetahui hubungan kualitas pelayanan Assurance terhadap kepuasan pasien Hipertensi. Penelitian ini merupakan penelitian kualitatif, dengan rancangan penelitian deskriptif. Sampel pada penelitian ini yaitu 4 pasien Hipertensi dan 2 tenaga kesehatan dengan total jumlah 6 orang informan. Hasil wawancara mendalam Indepth Interview menunjukkan terdapat hubungan kejelasan informasi, keramah-tamahan dan tuntas dalam pelayanan terhadap kepuasan pasien hipertensi di Community Health Center Bestari.
\end{abstract}

(C) 2019 JMMR. All rights reserved

Article History: Received 2019-Aug-21; Revised 2019-Aug-23; Accepted 2019-Aug-25

\section{INTRODUCTION}

According to the Regulation of the Minister of Health of the Republic of Indonesia Number 75 of 2014, Health Services is an effort provided by the Community Health Center to the community, including planning, implementing, evaluating, recording, reporting, and set forth in a system.

Community Health Center is a health service facility that organizes public health efforts and first-level individual health efforts, with more emphasis on promotive and preventive efforts, to achieve the highest degree of public health in the working area. ${ }^{-}$

Increased public awareness about health has led to demands to improve health services. One effort to anticipate this situation is by maintaining the quality of service. ${ }^{2}$

Quality health services can increase patient satisfaction and encourage these patients to come back so as to increase the credibility of health services in the community. ${ }^{-}$
Parasuraman, Zeithaml, and Berry put forward five dimensions of service quality arranged in order of importance as follow Reliability, Responsiveness, Assurance, Emphaty, Tangibles. ${ }^{4}$ The whole dimension is constantly changing dynamically depending on the quality of service. Customer satisfaction must always be assessed periodically so that it can be a reference and evaluation for hospitals to continue to improve the quality of their services..$^{5}$

Assurance guarantees, including knowledge, ability, friendliness, courtesy, and trustworthiness of personal contact to eliminate the nature of consumer doubts and make them feel free from danger and risk. ${ }^{-}$

Assurance is a dimension of service quality related to the ability to instill trust and confidence in consumers. The guarantee dimension covers the ability of the workforce to know the product, including the ability of employees and politeness in providing services, skills in providing security in utilizing the services offered and the ability to instill consumer confidence in the services offered. ${ }^{?}$ 
The results of Riskesdas in 2013 reported that the prevalence of hypertension in North Sumatra was $45.69 \%$ in the age group above 60 years for outpatients. Based on the disease causing death of inpatients in the District / City Hospital of North Sumatra Province, hypertension was ranked first with the proportion of deaths of $27.02 \%(1,162$ people), in the age group $\geq 60$ years by $20.23 \%(1,349$ people). $\stackrel{8}{-} \underline{9}$

According to the results of the study Budiarto, on the quality of health services at Enkareng Health Center there are points from the dimensions of physical appearance (tangibility) said to be good, with an average percentage of recapitulation of $80.36 \%$, the dimension of Reliability is good, recapitulation of $77.75 \%$. Dimension of Responsiveness, very good recapitulation of $82.61 \%$. Assurance dimension, very good, recapitulation of $82.25 \%$. Empathy (Emphaty) dimension is good, recapitulation of $76.70 \%$. ${ }^{10}$

Results of research conducted Handayani, about the quality of health services to patient satisfaction The results of the study were analyzed by comparing expectations and experiences that illustrate the level of patient satisfaction with health services in the tangible aspects of $72.76 \%$, reliability of $72.09 \%$, empathy $72.89 \%$, responsiveness $72.88 \%$, and guarantee $72.22 \%$. Overall satisfaction level, $72.58 \%$ categorized as satisfied. ${ }^{?}$

The initial survey was conducted by interviewing one of the elderly patients in the bestari health center, the researcher asked

"do you already know the information about Senam Lansia?"

"Yes, I know about the program but I don't understand how and where it is done. They already gave the information but I did not clearly hear it, for what purpose I do not know, so I was reluctant to follow it"

From the interview above there is a gap in the assurance dimension in the form of providing information about the hypertension program.

Along with the increasing number of hypertension sufferers in the working area of the Community Health Center, it makes the interest of researchers to examine whether there is a relationship between the quality dimensions of Assurance Assurance services to the satisfaction of hypertensive patients.

\section{RESEARCH METHOD}

This type of research is a qualitative survey to find out the relationship between the dimensions of quality Assurance Services to the satisfaction of hypertension patients at the Community Health Center Bestari Medan.

The research design was exploratory using the indepth interview method. The variables in this study consisted of the independent variables in the form of clarity of information, hospitality and completeness of service and the dependent variable in the form of hypertension patient satisfaction.

The population in the study were health workers and patients who were in the Community Health Center Bestari. The sample in this study consisted of 6 informants, 4 informants of hypertensive patients and 2 informants of health workers.

\section{RESULT AND DISCUSSION}

Community Health Center Bestari is located in Medan Petisah District, Jalan Rotan Baru No.1, Petisah Tengah, Kec. Medan Petisah, Kota Medan, North Sumatra 20111.

The study was conducted for 3 days on July 16 - July 18,2019 with a total of 6 informants, who were divided into 2 informants in the health worker category at the Bestari Health Center and 4 informants in the Hypertension Patient category. Then the research began to be done by interviewing informants in depth with voice recording devices and questionnaires that have been prepared. The research was carried out every day during the study day from 08.00 WIB - 12.00 WIB. Before the interview began, the researcher gave an explanation of the purpose of the interview and gave an informed consent sheet. On 18 July 2019, all informants had been interviewed.

\section{Clarity of Information on Patient Satisfaction in the Assurance Dimension}

The statement of the health worker informant about the clarity of the information provided to the patient is good and clear, it can be concluded that the health worker has provided information clearly and satisfies the patient in receiving information.

While hypertension patient informants' statements about the clarity of the information provided were good, the patient seemed satisfied with the information provided. Researchers also directly observe how health workers provide clear information to patients and can be categorized as good. 
Obtaining clear information is the patient's right wherever he gets health care. Information is a very important thing in Services, especially health services. In patient health services, they need very clear information about what is complained about, it is stated in PERMENKES No. 69 of 2014 concerning Hospital Obligations, namely providing true, clear and honest information about patients' rights and obligations.

Table 1. Interview Result of Clarity of Information on Patient Satisfaction in the Assurance Dimension

\begin{tabular}{|c|c|c|}
\hline No & Interviewees & Interview Result \\
\hline 1 & $\begin{array}{l}\text { (Health Workers } \\
\text { Informant } 1 \text { ) }\end{array}$ & $\begin{array}{l}\text { "We always direct the patient if he } \\
\text { is confused about where to go, } \\
\text { what pain do we always direct } \\
\text { him". }\end{array}$ \\
\hline 2 & $\begin{array}{l}\text { (Patients } \\
\text { Informant 1). }\end{array}$ & $\begin{array}{l}\text { "Health workers are also patient } \\
\text { in dealing with angry patients and } \\
\text { continue to explain in detail the } \\
\text { information that patients need" }\end{array}$ \\
\hline 3 & $\begin{array}{l}\text { (Patients } \\
\text { Informant 3) }\end{array}$ & $\begin{array}{l}\text { "In my opinion, the Community } \\
\text { Health Center officer is good at } \\
\text { delivering information, the doctor } \\
\text { is also good at providing } \\
\text { information. If there is something } \\
\text { important they always inform the } \\
\text { patients here" }\end{array}$ \\
\hline
\end{tabular}

Statements of several hypertension patient informants who had been interviewed regarding the clarity of information provided by health workers at the Community Health Center Bestari received good and clear information.

Service cannot be said to be of good quality without clear and concise communication between service personnel and customers. The message must be delivered accurately and efficiently. $\frac{11}{-}$

Clarity in providing information in accordance with what was revealed by Parasuraman, Zeithmal and Berry, Assurance, covers the ability of employees to provide information, the ability to provide security in utilizing the services offered and the ability to instill customer trust. ${ }^{4}$

In a study conducted by Kuntoro and Istiono, there were no respondents who stated that they were very dissatisfied and the majority of respondents said they were satisfied with the service. So it can be interpreted that most patients feel confident and believe in the ability of officers to serve patients well. In addition, patients are also not allowed to wait without any certainty when getting services. $\stackrel{12}{ }$

\section{Hospitality in Service to Patient Satisfaction in the Assurance Dimension}

Hospitality is a dimension that involves the flow of products / services to customers and is interpersonal. This dimension involves the attitudes, behavior, and verbal abilities of officers in interactions with customers. The positive attitude of the service personnel will attract customers. Maintaining a positive attitude shown through attitudes, ways of dress, and verbal cues is important in determining service quality and will form a good impression in the eyes of customers..$^{11}$

In hospitality, the services provided by health staff informants were categorized very well, as evidenced by health workers who required empathy and patience in dealing with patients. This is supported by the statement of a hypertensive patient informant who said that health workers at the Community Health Center Bestari were very friendly and patient in providing services. From the researchers' point of view, the staff of the Bestari Community Health Center have provided very friendly services to hypertensive patients at the Bestari Community Health Center so that it can be categorized very well and the patient looks satisfied with the service.

Table 2. Interview Result Hospitality in Service to Patient Satisfaction in the Assurance Dimension

\begin{tabular}{|c|c|c|}
\hline No & Interviewees & Interview Result \\
\hline 1 & $\begin{array}{l}\text { (Health Workers } \\
\text { Informant 1) }\end{array}$ & $\begin{array}{l}\text { "We always provide the best } \\
\text { service to patients. It must be } \\
\text { friendly, patient and empathetic } \\
\text { in conducting health services } \\
\text { because we face the sick" }\end{array}$ \\
\hline 2 & $\begin{array}{l}\text { (Health Workers } \\
\text { Informant 2) }\end{array}$ & $\begin{array}{l}\text { "If the service we provide is } \\
\text { appropriate but it returns to each } \\
\text { patient, if the standard is in } \\
\text { accordance" }\end{array}$ \\
\hline 3 & $\begin{array}{l}\text { (Patients } \\
\text { Informant 1) }\end{array}$ & $\begin{array}{l}\text { "Health workers here are very } \\
\text { friendly, they always face } \\
\text { patients patiently, and always } \\
\text { provide comfort" }\end{array}$ \\
\hline 4 & $\begin{array}{l}\text { (Patients } \\
\text { Informant 2). }\end{array}$ & $\begin{array}{l}\text { "I think the health workers here } \\
\text { are friendly, good. I feel } \\
\text { comfortable and believe in } \\
\text { treatment here". }\end{array}$ \\
\hline 5 & $\begin{array}{l}\text { (Patients } \\
\text { Informant 4). }\end{array}$ & $\begin{array}{l}\text { "I feel confident treating } \\
\text { here, the proof is that from } 1976 \text { I } \\
\text { always treated here" }\end{array}$ \\
\hline
\end{tabular}

Hospitality is one of the indicators that is very close to the assurance assurance consisting of competence, courtesy, 
credibility, and trustworthiness. ${ }^{-}$Hospitality is a behavior that can make others feel comfortable, calm and trusting. Good health services are health services that can provide comfort to patients.

In research conducted by Imam Khoirul, related to assurance services at the Community Health Center, the disease diagnosis process is carried out according to established procedures, doctors are skilled at work, nurses are skilled at work, staff have adequate understanding competence, doctors are polite and friendly in examining patients. $\frac{13}{}$

According to Pohan, states that in providing health services so that patient satisfaction occurs, quality services are needed. Quality services are health services that always try to meet patient expectations..$^{-}$

In the hypertension patient satisfaction survey conducted, the hospitality given by the health staff at the Community Health Center Bestari was very good. The majority of patient informants who were interviewed said that the health workers at the Community Health Center Bestari were very friendly and patient.

The nature of hospitality given by health center health workers is one of the advantages of the Community Health Center Bestari and makes patient loyalty according to Supranto satisfied customers will share satisfaction with producers or service providers. Even satisfied customers will share their taste and experience with other customers. ${ }^{14}$

From the results of an analysis conducted by Supartiningsih, it shows that the assurance variable has a positive and significant influence on patient satisfaction. This can be interpreted if the characteristics that can be trusted, friendliness owned by health workers increases, patient satisfaction will increase as well. $\frac{15}{}$

In a study conducted by Inna et al,where hospitals provide services always implement hospitality, courtesy, and skills to users of health services, so that customer satisfaction arises. $\stackrel{16}{ }$

Research conducted by Nurcaya, there is an attribute that is considered good by patients because the gap value of these attributes is positive such as the hospitality and courtesy of health care workers in providing services..$^{17}$

The following is the patient's statement about the positive things received from Community Health Center services, namely trust and loyalty.

The statement is in accordance with research conducted by Andriyani et al, that service with hospitality provided by service officers to patients is able to foster trust and security so that patients feel satisfied with the services provided. $\frac{18}{}$

\section{Completeness of Service to Patient Satisfaction in the Assurance Dimension}

The statement of the health worker informant about the completeness of the service provided to the patient is good. It can be concluded that the completion of providing services is categorized as good, this is evidenced by the statement of the informant who said that he had followed the SOP and did not leave a problem for too long. From the statement of the patient informant, it can be seen that the services provided by health workers are good and are carried out quickly and thoroughly, supported by the statement of one patient informant who quickly gets a referral letter without needing to queue for too long. From the researcher's point of view, health workers have provided complete health services both in the treatment and preparation of patient referral letters.

Completion in service is a procedure that is carried out until the patient leaves the Community Health Center feeling satisfied. The services are curative, promotive, preventive or just to ask for a referral letter to the Community Health Center. This is done completely without any obstacles that can make patients feel disturbed in receiving services. In providing completeness services is one form of procedure that must be performed by health workers from the patient received until the patient goes home. This will have an impact on patient confidence and comfort in the Community Health Center. In the satisfaction survey conducted, the Bestari Community Health Center was categorized as Good in thoroughly providing services to both general and BPJS patients.

"In my opinion they are complete in providing services to patients. Because this is strategic if they are not complete they usually refer. During treatment here it's always good and the service is fast "

(Patients Informant 3)

Research conducted by Adhytyo and Mulyaningsih shows that getting better and more precise in handling will increase the level of satisfaction. Timeliness is a condition where everything is done according to the time. Timeliness of service at the Community Health Center can also be interpreted as the length of service provided by the Community Health Center to patients. ${ }^{-19}$

In accordance with according to Parasuraman, Zeithmal, the ability to provide security in utilizing the services offered and the ability to instill customer trust in the company. .20

Based on research conducted by Budiarto, that officers in providing services always complete it thoroughly and 
thoroughly are good, this can be shown by most of the respondents' answers saying very complete The services provided by officers must be complete, this is very influential on patient satisfaction with service obtained. ${ }^{10}$ Health workers at the Community Health Center Bestari have understood and implemented the SOP as stipulated at the Community Health Center. The majority of patient informants said that they were satisfied with the services provided by the Community Health Center Bestari.

"The service we provide is a complete service and finished to the end. We also have to comply with SOPs that have been made about how to serve patients"

(Health Workers Informant 2).

Meeting the needs of patients will provide an overview of patient satisfaction. Therefore the level of patient satisfaction is very dependent on the patient's view of the quality of Community Health Center services. Patient needs include price, safety, accuracy and speed / completeness of service..$^{20}$

"They complete in doing services to patients, I am satisfied treatment here"

(Patients Informant 3).

According to Pohan, the success of a health service must be carried out in an appropriate manner and time, by the service provider, so that the creation of patient satisfaction with the services provided..$^{-1}$

\section{CONCLUSION}

From the results of research conducted at the Community Health Center Bestari, it can be concluded that the Assurance Service Quality Dimension which includes three factors, namely clarity of information, service hospitality and service completeness are strongly related to the satisfaction of hypertension patients at the Community Health Center Bestari Medan. The majority of informants felt very satisfied, trusted and comfortable with the services provided by the Community Health Center Bestari. The Community Health Center must maintain and continue to improve the quality of services provided to patients who visit so that patient satisfaction is maintained, giving rise to comfort, trust and loyalty of patients.

\section{REFERENCES}

1. Mboi, N. Peraturan Menteri Kesehatan Republik Indonesia Nomor 75. (2014).

2. Yuliani, U. Hubungan Kualitas Pelayanan Dengan Kepuasan Pasien Rawat Inap Di Rsud Dr. Sayidiman
Magetan Skripsi. Skripsi (2015).

3. Juliana. Hubungan Kualitas Pelayanan Dengan Kepuasan Pasien Rawat Jalan Di Rumah Sakit Uns. (2017).

4. Muninjaya, A. A. G. Manajemen Mutu Pelayanan Kesehatan. (Penerbit Buku Kedokteran Egc, 2015).

5. Mumu, L. J., Kandou, G. D. \& Doda, D. V. Analisis Faktor-Faktor Yang Berhubungan Dengan Kepuasan Pasien Di Poliklinik Penyakit Dalam Rsup Prof . Dr . R . D . Kandou Manado Clinic Of Internal Medicine Department Of Rsup Prof . Dr. R . D . Kandou. (2016).

6. Tjiptono, F. \& Chandra, G. Service, Quality, Dan Satisfaction. (Penerbit Andi, 2016).

7. Handayani, S. The Level Of Patient Satisfaction With Health Services In Baturetno Health Centers. 14, (2016).

8. Kementrian Kesehatan Ri. Hasil Utama Riskesdas 2018. 61 (2018). Doi:1 Desember 2013

9. Tarigan, A. R., Lubis, Z. \& Syarifah. Pengaruh Pengetahuan, Sikap Dan Dukungan Keluarga Terhadap Diet Hipertensi Di Desa Hulu Kecamatan Pancur Batu Tahun 2016. 11, 8-16 (2018).

10. Budiarto. Skripsi Kualitas Pelayanan Kesehatan Community Health Center Di Kecamatan Enrekang Kabupaten Enrekang. (2015).

11. Septiani, A. Pengaruh Faktor-Faktor Kualitas Pelayanan Terhadap Kepuasan Pasien Di Instalasi Gawat Darurat Rsud Kabupaten Sumedang. (2016).

12. Kuntoro, W. \& Istiono, W. Kepuasan Pasien Terhadap Kualitas Pelayanan Di Tempat Pendaftaran Pasien Rawat Jalan Community Health Center Kretek Bantul Yogyakarta. 2, (2017).

13. Imam Khoirul, F. Analisis Pengaruh Kualitas Pelayanan Kesehatan Terhadap Kepuasan Pasien Di Rumah Sakit Umum Daerah Kabupaten Karanganyar. (2016).

14. Andriani, A.-. Hubungan Mutu Pelayanan Kesehatan Dengan Kepuasan Pasien Diruangan Poli Umum Community Health Center Bukittinggi. J. Endur. 2, 45 (2017).

15. Supartiningsih, S. Kualitas Pelayanan Kepuasan Pasien Rumah Sakit: Kasus Pada Pasien Rawat Jalan. 6, 9-15 (2017).

16. Inna Sholihati Embrik, Siti Dyah Handayani, M. S. N. Persepsi Kepuasan Pasien Pada Kualitas Pelayanan Di Rumah Sakit Gigi Dan Mulut Universitas Muhammadiyah Yogyakarta. (2013).

17. Nurcaya, I. N. Analisis Kualitas Pelayanan Rumah 
Sakit Di Provinsi Bali. 1-22 (2012).

18. Ika Andriyanti, D. S. Hubungan Kualitas Pelayanan Dalam Lima Dimensi Pelayanan Dengan Kepuasan Pasien Di Rawat Inap Community Health Center Baki Kabupaten Sukoharjo. 1-13 (2016).

19. Rondonuwu, N. S., Sondakh, R. C. \& Ratag, B. T. Rawat Jalan Dengan Minat Untuk Memanfaatkan Kembali Pelayanan Kesehatan Di Community Health Center Ranotana Weru Kota Manado Tahun 2014. 17 (2014).

20. Subekti, D. Dengan Tingkat Kepuasan Pasien Balai Pengobatan ( Bp ) Umum Community Health Center Di Kabupaten Pengesahan Tesis Balai Pengobatan ( Bp ) Umum Community Health Center Di Kabupaten Tasikmalaya Tahun 2009. (2009).

21. Saragih, S. Hubungan Kualitas Pelayanan Dan Kepuasan Pasien Dengan Kunjungan Di Balai Pengobatan Gigi Community Health Center Kota Pekanbaru. (2009). 